\title{
Evaluation of citizenship education and values education in the early years of the republic
}

\author{
Sabri Becerikli ${ }^{1}$, Sevda Gülşah Yıldırım² \\ ${ }^{1}$ Faculty of Education, Social Studies Department, Bursa Uludağ University, Turkey \\ ${ }^{2}$ Faculty of Education, Kahramanmaraş Sütçü İmam University, Turkey
}

\begin{tabular}{l}
\hline \hline Article Info \\
\hline Article history: \\
Received Oct 29, 2019 \\
Revised Jan 11, 2020 \\
Accepted Feb 8, 2020 \\
\hline
\end{tabular}

Keywords:

Citizenship education

Values education

Republic

\begin{abstract}
Many governments in history have always wanted to educate their citizens according to their own perceptions. In the early years of the Republic, the administrators of the Republic of Turkey intended to educate citizens concurrent with the republican regime. The present study aims to investigate and reveal what kind of a citizen was desired to be educated in the first years of the Republic. From this point of view, numerous views of the administrators in the first years of the Republic were revealed and the citizenship education courses (Musahabat-l Ahlakiye and MalumatVataniye) which were included in the 1924 Primary Schools Program were addressed. In order for the course to be able to be evaluated in terms of aims and citizenship education, a sample book from the textbooks of Musahabat- Ahlakiye and Malumat-l Vataniye, which were taught in fourth and fifth grades in primary schools, was examined. The present study was designed with document analysis method, one of the qualitative research methods.
\end{abstract}

This is an open access article under the CC BY-SA license.

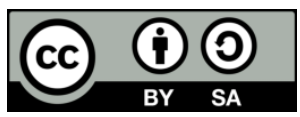

\section{Corresponding Author:}

Sabri Becerikli,

Faculty of Education, Social Studies Department,

Bursa Uludağ University,

Özlüce, Görükle Kampüsü, 16059, Nilüfer/Bursa, Turkey

Email: beceriklisabri@uludag.edu.tr

\section{INTRODUCTION}

It is a common phenomenon for the governments that administrate the state to get their own policies as well as those of the state accepted by their people and spread them. It was desired by the governments to raise individuals who were not only equipped in terms of knowledge and skills, but also who would represent the official understanding of the administration [1]. The most important condition for the continuation of the regime is the existence of the citizens who own it. The concept of citizenship is related to the bond that the state establishes thanks to the rules of law, the bond of individuals to the state and the compatibility of individuals to the society in which they live. It is only natural that citizenship education aims to achieve this compatibility [2].

The most essential mission in raising individuals has always fallen onto to the families and schools. For this reason, schools and education activities have become the usual field of intervention of the official ideology [1]. Training individuals as desired through interventions on education can be interpreted as reflection of understanding of social engineering in a way. When look Turkish Republic' first years, to run into similar situations are possible. On the purpose of determine that what citizenship is designed in Turkish Republic and this citizenship must have what moral principles in the present study is handled opinions of period administrators primarily, and is reviewed course books and curriculum which is thought having been prepared as reflections of this opinions. 
A framework based on the views of Mustafa Kemal directed Turkey's education system in the early years of the Republic. Mustafa Kemal introduced the new understanding and basis of the education in Turkey in the period of the National Struggle and the first years of the Republic [3]. Mustafa Kemal participated in the Education Congress held in July 1921 just before the Battle of Sakarya and visited schools during his travels to Konya, Kütahya and Bursa and emphasized that the education system must be the national, scientific and practical. He also insisted that the education system in the Ottoman Empire was an important cause of backwardness by seriously criticizing the education system left over from the Ottoman era [4]. With the declaration of the Republic, the duty of protecting and defending the Republic was added to the similar statements. The leaders of the new regime took an important step in education with the Law on Tevhid-i Tedrisat (Unification of Education) and thus made the first big move against the old understanding of education. Madrasas (Islamic theological schools) were closed down on the basis of this law and education was started to be built on the principles of the Republic [5].

The founders of the Republican regime claimed that they had established a new state and a new understanding that had no connection with the Ottoman era and Ottoman institutions [6]. Turkey that gained a new identity after the declaration of the Republic in 1923 intended to educate individuals according to this new identity. The fundamental changes in the education system were mentioned in the discourses of the administrators acting for this purpose and the administrators put their words into action. One of the most important pillars of these implementations was to change the curriculum and the textbooks. Apart from reducing the course hours of the theology course, even if there was not much of a change in terms of courses taught, the love of the Republic was instilled in the content of the courses offered [7-10]. The changes in question were reflected in the discourses of the people at the administration level. In an interview with a newspaper, the acting Ministry of Education Minister Vasıf Bey (Mr. Çınar) declared that all issues related to the Turkish education would be advanced according to the Republican spirit, that the curricula should be prepared according to the new guidelines, and that there was no place for the textbooks written in accordance with the old mentality at the new schools of the Republic of Turkey [11]. M. Kemal addressed the devoted teachers of the Republic at the Teachers Union Congress on August 25, 1924 and asked them to educate "academically, scientifically, mentally and physically" strong individuals with high moral values who would defend the Republic. M. Kemal concluded his speech with the following words:

Comrades, the military, political, administrative transformations that the new Turkey has managed to put together in few years' time are very enormous, very important. These transformations will be confirmed by your, you honorable teachers, accomplishments in the social and intellectual spheres. Never forget that the Republic wants you to educate generations that are intellectually free, conscientiously free, and scientifically free [9].

At the same congress, Vasıf Bey stated that following the footsteps of M. Kemal, the nation had moved away from the ancient superstitions and traditions and that the country would take its place among the civilized societies under the leadership of the teachers [9]. In a circular issued by the Ministry, it was stated that the educational objectives were to educate the young people well and change the education system accordingly for the survival of the Republic and the new state [12].

In the Elementary Schools Curriculum published in 1924, subjects such as the defense of the Republican ideology and the characteristics of the good citizens were mainly reflected in the content of Musahabat-ı Ahlakiye and Malumat-l Vataniye course [7]. Essentially, the foundation of this course to be included in the curriculum of the Turkish Republic schools were laid in the 2nd in the Constitutional Monarchy period, and a new understanding of citizenship available within the citizenship course of the Ottoman Era curriculums were tried to be introduced [13].In the Republican period too, the characteristics that the citizens should have based on the new ideology and the necessity of this ideology were emphasized in this course [7].

When the relevant literature is examined, it is possible to find many studies on what type of citizens to educate in the early years of the Republic [13-18]. It is clearly seen that some of these studies dealt with the subjects of citizenship [13,15, 17] and some others with morality [14, 18]. In the present study was examined understanding of role-model citizenship who was designed in the education system in the first years of Turkish Republic. In this context, it is aimed to reveal with the holistic point of view in this study what type of citizens were to be educated and what kind of moral education was to be given on the educational ground of the Republican period. For this purpose, Musabahat-l Ahlakiye and Malumat-l Vataniye course and its textbook were examined in depth. 


\section{RESEARCH METHOD}

In the present study, it is aimed to examine in terms of education system the characteristics of the citizens who were targeted to be educated in the first years of the Republic. For this purpose, the present study was designed with document analysis method, one of the qualitative research methods. Document analysis involves "the examination of the written responses of full texts of organizational, clinical or program records, or quotations, memorandums and correspondences, official publications or reports, and personal diaries to open-ended surveys" [19].

\subsection{Data collection tool}

In order to gather information about the characteristics of the citizens who were targeted to be educated in the Republican period, the course content and how the course of the Musahabat-l Ahlakiye and Malumat-l Vataniye was taught in the elementary school programs were dealt with. It is known that more than one textbook was used for the teaching of this course.

The textbook titled Musahabat-l Ahlakiye and Malumat-l Vataniye discussed in the present study was written by Orhan Fuad in 1924 as two volumes to be taught in the 4th and 5th grades of elementary school [24, 25]. During the Republican period, various textbooks of conversations and discussions on morality were written for elementary and secondary education [20, 21]. In addition, shortly before the declaration of the Republic, similar textbooks were written for schools [22, 23]. The works of Orhan Fuad, as far as we could trace them, were of importance in terms of being one of the first Musahabat-l Ahlakiye and Malumat-l Vataniye textbooks written for the elementary school level of the Republican period after the publication of the elementary school's curriculum of 1924 [24, 25]. In this study, on the other hand, the textbook of Musahabat-l Ahlakiye and Malumat-l Vataniye by Orhan Fuad was chosen amongst the other Musahabat-l Ahlakiye textbooks in order to carry out an in-depth analysis.

\subsection{Data analysis}

In accordance with the nature of qualitative studies, deductive content analysis was preferred. In the case of deductive analysis, the data are analyzed according to the existing frameworks [19]. A general framework was prepared by the researchers in accordance with the purpose of the study. The framework was composed of three titles "content, concepts and values". The two researchers made coding for each theme separately and the subsequent coding was compared. Where the researchers could not agree, the third researcher's opinion was sought. As a result of the analysis of three researchers, final findings were formed.

\section{RESULTS AND DISCUSSION}

In the findings part of the study, firstly, general information about Musahabat-l Ahlakiye and Malumat- $\iota$ Vataniye syllabus was given. The data was then divided into three themes: "the content of the course, concepts and values". The following are the details of each theme.

\subsection{Results}

\subsubsection{Musahabat-ı ahlakiye and malumat-i vataniye curriculum}

The citizens who were targeted to be educated in the first years of the Republic were defined in the elementary school program, as the individuals, as possessing the title of the citizen of the Republic of Turkey, whose acts and behavior are directed by moral principles and who are well aware of their statutory rights, and fulfills their national and humanitarian duties. In addition, the task of educating the desired citizen in the program was assigned to the content Musahabat-l Ahlakiye and Malumat-l Vataniye course [7].

During the Ottoman Empire era, the Malumat-l Medeniye course the state which was added to the curriculum with aim of encouraging the citizens to love the country, the state and the idea of family union and educate them as citizens who were prone to show obedience to all these concepts was named as the Musahabat-l Ahlakiye and Malumat-l Vataniye course with the addition of Ottoman criticism and love of the Republic to its content [7, 13].

Musahabat-l Ahlakiye course was included at all levels of the elementary school. In the 1924 curriculum, it was mentioned that only the 4 th and 5 th grades would be given the textbooks. Before tracking down the textbooks in the upper classes, in the 1st, 2nd and 3rd grades, the way the Musahabat-l Ahlakiye course was conducted in the form of conversations, teacher's moral suggestions, stories of great national heroes, great scholars, explorers, inventors, especially the story of the adventures of children heroes in the form of attractive stories was appreciated. It was believed by the drafters of the 1924 Program that education in the first three years would have a significant impact on the morality and spirituality of children. According to the drafters, the adventures of the great personalities and heroes, which were important for humanity, would have the effect that the scholastic and lifeless moral rules cannot provide. The heroes 
always set an example for children to be virtuous. In addition, it was believed that children should get good habits adopted. For this reason, it was emphasized that schools should be organized in a way that could give children positive behaviors such as cleanliness, order, courtesy, honesty, cooperation and solidarity [7].

In the conversations part of the Musahabat-l Ahlakiye course, it is possible to see some rules and guidelines that form the basis of educational psychology today. In order to enable children to participate in school life from their first days, it was aimed to provide them with small tasks according to age groups, work together in order to organize areas such as library and school yard, and thus develop the spirit of cooperation and solidarity among children. The teachers were recommended to chat with children and engage in dialogue with them, draw attention to the good and bad behavior they showed in and out of school, give them opportunities to engage and engage children in all material and moral issues related to their school, give them tasks within their capabilities and provide an environment and opportunities that would allow children to discover their personalities. In this way, it was believed that the next generation of citizens would be able to express their ideas and thoughts easily, defend their rights, consider the interests of the society rather than their personal interests, and recognize the laws and obey them;

It was recommended that they be educated as active, dynamic, enterprising, conscientious and competent citizens of the Turkish Republic. The young people who grew up in our schools learned from their own experience that the most successful and perfect style of administration was the Republican administration and would not hesitate to make any sacrifice for the defense and protection of the Republic" [7].

In the 4th and 5th grades, the lessons were taught through the book [7]. In the 4th grade, the individual, society, the duties of an individual to himself/herself, his/her family, nation and humanity, the health, cleanliness and discipline duties, the measures to be taken to ensure the comfort of the citizen, and the rules that the citizen should comply with in order to facilitate the work of the municipalities were included.

In the 5th grade, subjects such as the motherland, the nation, the state, the government, the best form of government, the benefits of the Republic, the War of Independence, the opening of the Parliament, the declaration of the Republic, the Constitutional Law, political rights provided to the citizens, freedom, equality, municipal and parliamentary election, state budget, administrative organizations (province, district, township), duties of the state to ensure the public order, orphans and widows, martyrs and poor children, the ill, the disabled, institutions established for the veterans, citizens' duties towards the Republic of Turkey (to obey the laws, tax giving, military service), reverence to the Turkish banner, patriotism, sacrifice against the motherland, defense of the Republican administration with heart and soul were included [7].

The books that were taught in the Musahabat-l Ahlakiye and Malumat-l Vataniye in the 4th and 5th grades were prepared by Orhan Fuad according to the 1924 curriculum and accepted by the Ministry of Education. The first pages of the books comprised of the content prepared according to the curriculum. It consisted of five chapters in two books $[24,25]$. For the purpose of this book, various themes were created for a detailed examination of the book. Related findings under the title of content, The following are the concepts and values given

\subsubsection{Content}

Under this theme, findings related to the content of textbooks according to grade levels are presented. In the 4 th grade textbook, mostly the concepts such as respect and duties of citizens to the state and institutions, their respect to family and society, gratitude and sacrifice were covered. One's morality, virtue and understanding of the value of the period were introduced and students were recommended on how they should behave. Morality was regarded as the equivalent of the love of homeland, and the philosophy of the one who has morals loves his/her country was recognized. In addition to these subjects, the structure of the municipalities and their duties to the citizens constituted a large part of the book [24].

5 th grade is a period in which a little more technical knowledge was given compared to 4th grade. In the textbook, the duties of the government and the citizen were included in a very small section. A student who learnt the moral rules in the first four years was expected to learn the subjects such as:

What is a country and nation? What is the government? What is the state? How many types of governments are there? What is constitutional monarchy? Which type of these governments is good? The history of the struggle of independence, the formation of the Grand National Assembly of Turkey, the proclamation of the Republic of Turkey, the benefits we have had and will have of these concepts, what kind of rights does the Republic provide us? What is Independence? Types of Independence, the other laws of citizens, the right and 
importance of elections, elections in our country, how to be elected as members of the National Assembly?

In the last year, and thus the students were expected to be ethical and well-behaved as well as knowledgeable, who loved the republic and were hardworking citizen. The courses were conducted on the basis of as one lecture and one discussion session [25].

\subsubsection{Concepts}

Under this theme, findings related to the concepts of homeland, nation and republic which were frequently mentioned in the 4th and 5th grade textbooks. While some knowledge and information presented in the textbooks was given about how the state organization functioned, it was also tried to teach the definition and contents of important concepts in order to internalize the existing ideology. Furthermore, as was previously mentioned, suggestions were made through the book for the new regime to get itself accepted by the citizens and educate individuals to defend it $[24,25]$.

In the 5th grade textbook, the homeland was not regarded only as a place of birth, where one grew up and lived. Even if a person was born somewhere, if he did not have the citizenship rights of that country, it was not defined as homeland for him/her. Those who had the same political rights regardless of race, religion or language were considered as citizens. The concept of nation, on the other hand, articulated the individuals who were connected to each other in terms of race, language and custom even if they lived in different lands. In the textbook, it was stated that the most populous nation in the world was the Turkish nation by emphasizing the Turks living in other states. Another important point highlighted in the textbook was the distinction between the concepts of citizen and member of a nation. While the concept of citizen was defined through political rights, the concept of member of a nation was defined through race. Moreover, love of scoring was made between the concepts of citizen and member of a nation. There was no obligation that the citizen and the member of a nation had to live in the same country. However, it was emphasized that those who were from the same nation and who lived in the same country were loved more than those who were only citizens or members of a nation. In other words, Turkish citizens were considered superior to nonTurkish individuals, although they were accepted as citizens. As a reason for this situation, it was shown that culturally the Turks had closer ties between them [25].

In the textbook, the concepts of autocracy, constitutional monarchy and republic were explicated in a simple way and the answer to the question "Why should the regime of Republic be preferred?" was given through the comparison of these regimes. In order to educate the younger generations as a republican, while the good aspects of the regime were emphasized, at the same time the Ottoman administration was criticized either directly or indirectly. According to the book; in autocracy, it was not considered sufficient for the sovereign to be just and good-intentioned. Even if the sovereign was not evil, it was argued that the possession of power by a single individual would somehow lead to abuses. As an example, it was emphasized that a civil servant appointed by a fair and good sultan could persecute him. Nevertheless, the textbook also contained criticism that directly disparaged the sultan:

The treacherous hearted, cowardly sultan [Mehmet Vahdettin] and his loyal delegation appointed by him did not make any criticism against these barbaric movements, they were mere spectators, they sucked up to the British; they crushed many Muslims with the words of British. And the British; they deceived the traitor Sultan Mehmet Vahdettin by overtaking the so-called treacherous grand vizier DamatFerit. In Anatolia, the mujahedin who took up arms to save the religion and nation and homeland were declared as rebels; they distributed fatwas (Islamic religious law) around. The ignorant people of some countries almost believed in them. But it was luckily prevented; the public again were reunited [25].

Another criticism of autocracy was the claim that for the existence of free newspapers and books in which the people could make their voice heard, tolerance level of the autocratic regime was low [25]. On the other hand, the commonalities of constitutional monarchy and the republic were welcomed. In the textbook, it was often stated how good the two regimes were in terms of the existence of parliament and the rule of law. However, the existence of the sovereign was seen as a problem in the constitutional monarchy and the position of the sovereign to intervene at any time was put forward as a drawback for the administration of the constitutional monarchy. In the Republican regime, on the other hand, it was emphasized that such problems did not exist and that the fact that the president of the state would only come to power in every 4, 5 or 7 years was seen as the control of the citizen over the administrator. This situation was justified in the book as follows: "If the President does a minor injustice, nobody will vote for him in the elections in the second term of his office. For the second term of office, the President would not do 
any injustice with the desire to be elected; he would continuously think of the interest and benefits of the people" [25].

In the textbook, it was stated that one of the benefits of the Republic was the Constitution. Equality, conscience, idea, speech, writing, traveling, working, acquiring property, establishing associations, establishing companies, and freedom of electing and being elected were among the benefits provided to the citizens of the Republic [25]. For instance, examples such as:

Every Turk is equal according to the law. There are no privileges for class, family or individual." "Possessions and property, we possess cannot be seized by someone else. No one's letter can be opened and read. No one can be compelled to go from one court to another court. No one's property can be confiscated by the government...." “... No individual may be used in labor. Nothing can be taken from any person under the name of tax and duties unlawfully. However, the nations governed by an Absolute Ruler are deprived of such rights and interests. He does not possess any of the kind of freedom [25].

Reasons were given and it was argued that the Republic was the best form of government [25]. However, it was ignored that similar issues were also mentioned in the Tanzimat Edict (Imperial Edict of Reorganization) [26]. In the textbook, the right to elect and be elected, which was an important issue for the Republican regime, was also covered and women's rights were not forgotten. However, it was also mentioned in the textbook in the relevant section that the level of education of women had not yet reached the level where they could claim their rights. Even though women did not have this right at the time when the textbook was written, it was stated that they would have the right to elect and be elected when they would have more opportunities for education in the future [25]. Before long, women were granted the right to elect and be elected for municipal elections in 1930, village elections in 1933, and parliamentary election in 1934 [27].

\subsubsection{Values}

In Turkish history, even if there were logical differences in political understanding, the fundamental understanding of value in morality did not change much $[1,28]$. The respect for religion and the Sultan in the Ottoman Empire era [1], was reflected as respect for the republican elements in the Republican Turkey [29]. In addition, bravery, wisdom, generosity, respect for parents, endurance, love of homeland, freedom, caring for family unity, independence, courage, generosity, feeling ashamed, bravery, justice, kindness, equality, respect for humanity, friendship, honesty, love, values such as helpfulness, cleanliness and health can be presented as examples for the continuation of this understanding [28, 30-33].

As was mentioned above, there are differences in some subjects between 4th and 5th grade textbooks. In the 5th grade textbook, more technical information was given and concepts such as state, republic, homeland and law were explained. In the 4th grade book, the values that were desired to be given under the name of the duties of the citizens were emphasized [24, 25]. As a result of the analysis of the textbook, the values and the indicators of the values as behavior that the citizen should have are presented in Table 1 as shown in appendix.

As can be seen from the table, it was revealed that the values desired to be taught to children in the Republican period in the textbook examined were giving importance to family unity, diligence, stamina, sensitivity, honesty, cooperation, moderation, importance attached to being healthy, respect, affection, persistence, being determined, responsibility, cleanliness, patriotism, loyalty and charity. It was found that the most emphasized values in the textbook were the importance of being healthy, cleanliness, charity, respect and obedience to the adults $[24,25]$. In addition, statements related to the behavioral indicators of each value were also included. Regarding the indicators of the value of love behavior, for the value of loving all people, while the statement: "After our family, neighborhoods and fellow citizens, we must love all people." was used, for the behavior of being loyal to the members of other nation in our country, the statement "If a member of a nation does not like other members of other nations, that nation cannot be contended and happy." was used. Regarding collaboration, as an example for the indicator for the sense of working together, the following statement can be shown; "One cannot work or succeed alone in this world. S/he needs the knowledge, ideas, money and heritage of others." For the value of responsibility, there were indications for the duties to the state that the citizen should fulfill. Regarding the subject in the textbook, the following statement is available; "I own the right to citizenship because I pay taxes to the government, do my military service at any time the government asks me to do it, and I respect and obey all the laws." Furthermore, examples from daily life reflected the value of responsibility as well. The following statement was in the textbook that "When I buy vegetables, bread, fruit from the bazaar and the market, and after I bring them home, if I realize that they are rotten and bad for health, I must go and inform the city officials." 
The value of moderation, which is not seen in the relevant literature today, appears to be in such a statement; Feeding oneself enough to keep our body strong and rest the body sufficiently.

In the textbook on this subject, children were given recommendations with the following statements; "We should eat moderately; neither too little not to feel hungry again nor too much to fill our stomach" and "We should sleep moderately: neither to little not to feel rested not too much to feel lazy." In relation to the value of faithfulness, there was a clear statement as the indicator regarding the sense of feeling gratitude to the people who produced for the benefit of the nation. The importance of being faithful was emphasized with the following statement in the textbook; "Imagine a piece of bread. We can clearly see the efforts, intellectual and scientific service of hundreds of thousands of people in the past who put their effort into it for it to take the form of bread." It is seen that there were many examples about values in the daily life in the textbook.

In the Musahabat-l Ahlakiye course, it was often emphasized that not having values and behaving contrary to the values would be condemned by the society. As a method of teaching children the values, it was observed that the method of telling about incidences that the role-model people experienced, stories, poems were used and the suggestion approach was adopted [24, 25].

\subsection{Discussion}

In the relevant literature, studies similar to the present one was found. However, it was observed in other studies that the subjects of either citizenship or morality were examined individually. When the study of Çelik [17], which dealt with the subject of citizenship, was examined, it was revealed that what type of citizen was desired to be educated in line with the objectives of courses such as history, geography, musahabat-l ahlakiye, malumat-l vataniye and civics, especially in the curricula of elementary schools of 1924 and 1926.

In Altındağ's [15] study, not only the first years of the Republic but also the following years were discussed. Altındağ [15] examined the citizenship information included in the Civics and Civil Knowledge textbooks in his study. The researcher also examined the concepts of homeland, nation, concepts related to Turkish and Turkishness, the perception of citizenship and the perception of the relevant period mentioned in the textbooks. Altındağ also discussed the Ottoman and Sultan criticisms in the books. One of the important studies on citizenship issues is Üstel's [13] book titled 'In Pursuit of Acceptable Citizen'. In this study, Üstel discussed both Ottoman and Republican periods. Üstel, who examined more works than other studies, showed in detail the process of transition from being a national subject to citizenship and the understanding of citizenship that was desired to be created. In addition, Coşğun [16] examined the philosophical and sociological trends that affected the contents of books on citizenship education by using similar sources.

When we look at the studies that mainly dealt with moral issues; in addition to the Civics and Civil Knowledge textbooks, in his study, Yinilmez Akagündüz [18] also examined the books of Culture of Religion and Knowledge of Ethics. Even though Yinilmez Akagündüz talked about nation and Turkishness concepts and citizenship issues, he mostly dealt with the moral teachings in these textbooks. In this study, the moral characteristics of a good citizen were examined by taking examples from the passages in the books. Another study on moral issues was conducted by Alabaş [14]. In the study of Alabaş, he tried to reveal the features of the curricula called values under the name of morality by examining a single work in depth.

The work titled "Resimli Yeni Musâhabât-1 Ahlâkıye and Medeniye", studied by Alabaş, belongs to 1924. The study was investigated under three titles as "the general information in the book, the teaching approach, and the characteristics desired to be taught to the individual". In his study, Alabaş listed the values desired to be taught under the title of "characteristics desired to be gained to the individual" under the subheadings of individual development, social harmony and religious beliefs. In this listing, the values of "caring for the family, honesty, morality, diligence, responsibility, paying attention to health, sense of shame, cleanliness, spiritual well-being, charity, environmental awareness, not being proud, frugality, being helpful" were considered in the individual development category. In the social cohesion category, "respect for rights, civic responsibility, solidarity, patriotism and love of the national banner, and adherence to customs" were included. In the religious beliefs category, "faith" was described as a value. There are some differences as well as similarities among the other studies and the present study regarding the investigation of the books on citizenship of the Republican era and what kind of a citizen was desired to be educated. Çelik [17], Altındağ [15] and Üstel[13]discussed the political and political perspectives of citizenship mostly and examined the objectives of the political power for the Republican citizens to have a particular political perspective. In Çelik's [17] study, it was observed that some important issues that might be seen in the textbooks were not mentioned. This may be due to the researcher's focus only on the objectives of the curricula in the study. The works of Altındağ and Üstel, where more than one work was examined, dealt 
with a certain period from the first years of the Republic until the following periods and revealed how the concepts of state, homeland, nation and Turkishness were perceived.

In the present study and in Altındağ and Üstel's study, where some racist discourses and Ottoman criticism were present, similar results were obtained in terms of how the concepts of state, homeland, nation and Turkishness were perceived in the early years of the Republic and in terms of the discourses used on racist discourse and Ottoman criticism and the opinions of the administrators of the period. However, the present study also differs from the mentioned studies in terms of examining the values to be taught to the individuals. Coşğun's [16] study, which can also be evaluated within the framework of citizenship concept, not only revealed the which philosophical and sociological movements the Civic textbooks examined in the study contained, but also covered the characteristics of the desired citizens as in the other works as well as the present study.

The studies of Yinilmez Akagündüz [18] and Alabaş [14], which placed the moral issues on the focal point of their studies, revealed similar results as well as differences when compared with the present study. Yinilmez Akagündüz discussed the passages he received from the books in terms of moral doctrine and focused on moral education in the Republican period. In the works he examined, Yinilmez Akagündüz emphasized the moral characteristics of the good citizen such as being honest, reliable and truthful and pointed out that a common national ethics was introduced in the books for social cohesion. In the present study, on the other hand, the issue of being honest and reliable was discussed within the scope of the values to be taught and similar results were obtained in terms of the moral characteristics of the citizens.

However, with the present study which is different from Yinilmez Akagündüz's [18] study, since only one single work was examined in depth, it was revealed which individual values were desired to be taught. Similar results were obtained with Alabaş who examined a different textbook. Alabaş divided the values that were desired to be taught into three categories as individual, society and religious and obtained the values of "caring for the family, righteousness, honesty, diligence, responsibility, attention to health, sense of shame, cleanliness, spiritual well-being, charity, environmental awareness, not being proud, frugality, being useful, respecting other's rights, citizenship responsibility, solidarity, patriotism and love of the national banner, adherence to customs and faith" were obtained from the textbooks he examined. In the present study, on the other hands, it was found that the values of "love, diligence, collaboration, charity, responsibility, respect, honesty, caring for family unity, being healthy, moderation, cleanliness, loyalty, persistence or perseverance, endurance (fortitude), patriotism and sensitivity" were targeted to be taught.In both studies, while some similar values were found, there were also some different values. In the Musahabat-l Ahlakiye and Malumat-l Vataniye textbook, which was examined in the present study, the values of "persistence, fortitude and moderation", and in the book titled Yeni Musâhabât-l Ahlâkiye and Medeniye, which was the work examined by Alabaş, the values of "environmental consciousness, not being proud and faith" are the observable differences between the two studies. The fact that two different textbooks that were published in the same year conflict with each other in terms of the mentioned values suggests that the boundaries of moral elements in the school textbooks were not clearly drawn in the early years of the Republic and that they did not have a clear instruction in this subject in their curricula. In this particular context, even though the two studies reached similar results in terms of values, it is important to observe in this comparison that there was no complete harmony between the books in terms of their contents in the early years of the Republican period.

\section{CONCLUSION}

In the present study, citizen education policy in the early years of the Republic of Turkey was examined. In this study, in addition to addressing the political and social consciousness imposed on the concept of citizenship, which moral characteristics the citizens should have were also emphasized. In order to reveal the citizen model that the administrators of the Republican period wanted to generate, the curricula of the period, the discourses of the politicians were examined and especially one of the textbooks was selected and in-depth analysis was conducted.

It can be interpreted in the manner of this study indicated the citizenship style plan of administrators and also reflection of this to textbooks' content through curriculum in the first years of Turkish Republic. The present study has not only focused on how a citizen should be politically trained, but also what individuals have moral values. Although there are studies dealing with different dates regarding citizenship and value understanding in the Republican era, increasing the relevant researches may contribute to the formation of more literature knowledge. This case may be useful for a more accurate comparison of practices in the Republic of Turkey. In addition, conducting similar study in different countries can be contribute to both comparison of countries' understanding and to formation of core knowledge in terms of whether there are same understanding in the another countries and if any, which ways reflected to education. 


\section{REFERENCES}

[1] N. Doğan, Ders kitaplarl ve sosyalleşme (1876-1918), İstanbul: BağlamYayınları, 1994.

[2] Ş. V. Hablemitoğlu and E. Özmete, "Etkili bir vatandaşlık eğitimi için bir öneri," Ankara Sağglk Bilimleri Dergisi, vol. 1 , no. 3 , pp. 39-54, 2012

[3] C. Öztürk, "Çağdaş eğitim ve bilim," Öztürk, C. (Eds.), Imparatorluktan ulus devlete Türk inkılap tarihi, pp. 241264, Ankara: Pegem Yayınları, 2005.

[4] A. B. Palazoğlu, Atatürk’ün eğitimle ilgili düşünceleri. Ankara: MEB Yayınları, 1999.

[5] M. Gündüz, Maariften eğitime, Ankara: Doğu-Batı Yayınları, 2016.

[6] F. Ahmad, Modern Türkiye'Nin oluşumu (14. ed.), İstanbul: Kaynak Yayınları, 2015.

[7] İlk Mektepler Müfredat Programı (IMMP), 1340.

[8] İ. Başgöz and H. E. Wilson, Türkiye Cumhuriyetinde eğitim ve Atatürk. Ankara: Dost Yayınları, 1968

[9] Ergün, M., Atatürk devri Türk eğitimi (2. ed.). Ankara: Ocak Yayınları, 1997.

[10] E. Aslan, “Türkiye Cumhuriyeti’nin ilk ders kitapları.” Eğitim ve Bilim, v. 35, no. 158, pp. 215-231, 2010.

[11] Hâkimiyet-i Milliye, March 9, 1924.

[12] Hâkimiyet-i Milliye, September 4, 1924.

[13] F. Üstel, Makbul vatandaşın peşinde II. Meşrutiyet'ten bugüne vatandaşlık eğitimi (3. Baskı). İstanbul: İletişim Yayınlar1, 2008

[14] R. Alabaş, "Cumhuriyet'in ilk yıllarında ilk mekteplerde insani ve toplumsal değerler eğitimi: resimli, yeni musâhabât-1 ahlâkıye ve medeniye ders kitabı örneği," Çağdaş Türkiye Tarihi Araşstırmaları Dergisi, XVIII (36), pp. 55-87, 2018.

[15] A. Altındağ, "Tek parti dönemi’nde (1924-1946) ilkokullarda vatandaşlık eğitimi," Unpublished master's thesis, Dokuz Eylül Üniversitesi, İzmir, 2013.

[16] S. Coşğun, "Atatürk dönemi yurt bilgisi ders kitaplarının eğitim felsefesi ve sosyolojisi açısından değerlendirilmesi," Unpublished doctoral dissertation, Erzincan Üniversitesi, Erzincan, 2015.

[17] H. Çelik, "Cumhuriyet dönemi vatandaşlık eğitiminde önemli adımlar." Sakarya Üniversitesi Fen Edebiyat Fakültesi Dergisi, vol. 10, no. 1, pp. 359-369, 2008.

[18] S. Yinilmez Akagündüz, "Cumhuriyet'in ilk yıllarından günümüze ders kitaplarında ahlak eğitimi," Unpublished doctoral dissertation, Ankara Üniversitesi, Ankara, 2016.

[19] M. Q. Patton, Nitel araştırma ve değerlendirme yöntemleri. (Çev. Ed. M. Bütün \& S. B. Demir). Ankara: Pegem Akademi, 2014.

[20] Ali Kami, Musahabat-ı ahlakiyemalumat-ivataniye. İstanbul: Orhaniye Matbaası, 1926.

[21] Muslihiddin Adil, Malumat-ı ahlakiye ve medeniye. İstanbul: Orhaniye Matbaas1, 1923.

[22] Ali Seydi, Musahabat-ı ahlakiye, diniye, tarihiye, medeniye. İstanbul: Orhaniye Matbaas1, 1335.

[23] Mehmed Asım and Ahmed Cevad, Anadolu yavrusunun kitabi. İstanbul: Evkaf-I İslamiye Matbaas1, 1340-1338.

[24] Orhan Fuad, Musahabat-l ahlakiye ve malumatı vataniye $-4^{\text {th }}$ grade. İstanbul: Kanaat Matbaas1, 1340a.

[25] Orhan Fuad, Musahabat-ı ahlakiye ve malumatı vataniye $-5^{\text {th }}$ grade. İstanbul: Kanaat Matbaas1, $1340 \mathrm{~b}$.

[26] E. Z. Karal, Osmanlı tarihi- 5. Cilt (8. ed.). Ankara: Türk Tarih Kurumu Yayınları, 2007.

[27] S. Gökçimen, "Ülkemizde kadınların siyasal hayata katılım mücadelesi." Yasama Dergisi, vol. 10, pp. 5-59, 2018.

[28] U. Kaya, Tanzimat'tan Cumhuriyet'e Osmanlı'da ahlâk eğitimi. İstanbul: Dem Yayınları, 2013.

[29] Orhan Fuad, Musahabat-ı ahlakiye ve malumatı vataniye. İstanbul: Türk Matbaası, 1342.

[30] F. Çetintürk, C. Çürük, A. Ustaoğlu, H. Karaçalı, S. Kaşevekoğlu and Ç. Kozaner, Sosyal bilgiler eğitimi açısından Kınalızade Ali Efendi'nin ahlak-ı ala'I üzerine okumalar. Ata, B. (Eds.), Ankara: PegemYayınları, 2011.

[31] İ. Kafesoğlu, Türk milli kültürü (40. Baski). İstanbul: Ötüken Yayınları, 2014.

[32] H. Ekşi and A. Katılmış, Karakter eğitimi el kitabı (3. ed.), Ankara: Nobel Akademik Yayıncılık, 2014.

[33] Sadi Şirazi, Bostan ve gülistan (1. ed.), İstanbul: Aras Yayınları, 2013. 